\title{
Dinamika Resiliensi Istri Pada Pernikahan Beda Agama
}

\author{
TITANIA CAESARY RACHMADHANI \& IKE HERDIANA* \\ Departemen Psikologi Sosial, Fakultas Psikologi Universitas Airlangga
}

\begin{abstract}
ABSTRAK
Penelitian ini bertujuan untuk mengetahui dinamika resiliensi pada istri di pernikahan beda agama ditinjau dengan menggunakan teori resiliensi milik Wille, Bettge dan Ravens-Sieberer. Faktor-faktor yang mempengaruhi proses resiliensi antara lain faktor resiko, faktor protektif, stres, kemampuan koping dan kompetensi individu. Metode penelitian ini menggunakan pendekatan kualitatif dengan menggunakan metode studi kasus intrinsik. Teknik penggalian data yang digunakan adalah wawancara mendalam dari partisipan disertai wawancara significant other lalu dianalisis menggunakan analisis tematik theory driven. Partisipan berjumlah 2 orang istri yang telah menikah dan memiliki suami yang berbeda agama. Partisipan pertama beragama Hindu dengan suami yang beragama Islam, usia pernikahan 25 tahun dan partisipan kedua beragama Kristen dengan suami yang beragama Islam, usia pernikahan 23 tahun. Hasil penelitian ini menunjukkan kedua partisipan memiliki stres yang berbeda pada pernikahan beda agama yang dijalani sehingga mempengaruhi faktor protektif, faktor resiko kemampuan koping dan kompetensi individu yang dimiliki masing-masing partisipan.
\end{abstract}

Kata kunci: istri, pernikahan beda agama, resiliensi

\section{ABSTRACT}

This study aims to determine the dynamics of resilience in wives in interfaith marriages in terms of using the resilience theory. Factors that influence the resilience process include risk factors, protective factors, stress, coping abilities and individual competence. This research method uses a qualitative approach using the intrinsic case study method. The data mining technique used was in-depth interviews with participants accompanied by significant other interviews and then analyzed using theory driven thematic analysis. The participants are 2 wives who are married and have husbands of different religions. The first participant is Hindu with a Muslim husband, marriage age 25 years and the second participant are a Christian with a Muslim husband, marriage age 23 years. The results of this study indicate that the two participants have different stress on interfaith marriages, which affect the protective factors, risk factors for coping abilities and individual competences of each participant.

Keywords: interfaith marriage, resilience, wife

Buletin Penelitian Psikologi dan Kesehatan Mental (BRPKM), 2021, Vol. 1(1), 209-220

*Alamat korespondensi: Fakultas Psikologi Universitas Airlangga, Kampus B Universitas Airlangga Jalan Airlangga 4-6 Surabaya 60286. Surel: ike.herdiana@psikologi.unair.ac.id 
sehingga penggunaan, distribusi, reproduksi dalam media apapun atas artikel ini tidak dibatasi, selama sumber aslinya disitir dengan baik.

\section{PE N D A H U L U A N}

Pernikahan merupakan proses penyatuan dua individu dari jenis kelamin berbeda yang dilakukan secara sah dan diketahui secara umum dan kemudian menjadi suatu institusi sosial dan dapat dijelaskan secara singkat bahwa pernikahan adalah ikatan suci antara pasangan dari seorang pria dan seorang wanita yang dianggap telah berusia cukup dewasa (Dariyo, 2003). Agama merupakan syarat penentu resminya suatu pernikahan dan sudah pasti akan menjadi masalah dalam proses pelaksanaannya. Permasalahan sering muncul apabila pasangan dari mempelai ini merupakan pasangan yang berbeda secara agama, karena Undang-Undang nasional tidak mengatur tentang kemungkinan timbulnya pernikahan beda agama ini (Hutapea, 2011).

Pernikahan beda agama di Indonesia semakin sering dibahas dan semakin mendapatkan perhatian oleh masyarakat dengan mendapatkan momentum dan relevansinya yang disebabkan oleh maraknya pernikahan berbeda agama dan diskusi publik terkait fenomena tersebut. Seiring dengan perkembangan yang terjadi di masyarakat Indonesia yang bisa dikatakan semakin kompleks, secara otomatis akan diikuti dengan permasalahan yang kompleks pula, seperti contohnya dalam masalah perkawinan, yang dimana perkawinan campuran, kawin kontrak dan perkawinan beda agama, dan yang akan menjadi fokus pada penelitian ini adalah pernikahan beda agama. Diketahui bahwa pada tahun 2011, terdapat 229 pasangan beda agama yang menikah dan tercatat sejak tahun 2004 hingga 2012 terdapat 1.109 pasangan beda agama yang melangsungkan pernikahan dimana sebagian besar pasangan yang menikah beda agama merupakan seorang pemeluk agama Islam dan Kristen, lalu Islam dan Katolik, Islam dan Hindu, Islam dan Budha, hingga yang paling jarang ditemui adalah Kristen dan Budha. Diketahui juga bahwa Jabodetabek merupakan peringkat nomor satu terbanyak yang terdapat pasangan menikah beda agama sebanyak 174 keluarga (Akbar, 2020).

Pada kasus pernikahan beda agama juga memiliki beberapa dampak yang ditimbulkan. Dampak tersebut antara lain tekanan dari dalam diri sendiri yang berupa keinginan untuk beribadah bersama dengan pasangan, mendominasi anak untuk pendidikan dalam agama dan ketidaksetujuan pihak keluarga serta stigma negatif dari masyarakat. Masalah yang timbul dalam pernikahan beda agama sering kali muncul dan dapat mengakibatkan rusaknya hubungan komunikasi antara suami dan istri, sehingga hal ini dapat menurunkan kualitas hubungan dalam pernikahan itu sendiri, seperti konflik khusus yang sejalan dengan adanya perbedaan agama dalam pernikahan yang dijalani oleh pasangan tersebut (Hikmatunnisa \& Takwin, 2007). Permasalahan, konflik serta dampak di dalam sebuah hubungan pernikahan beda agama membutuhkan upaya dalam pengelolaan masalah dari pasangan yang menjalani hubungan tersebut. Penelitian yang dilakukan Pratiwi (2014) menjelaskan bagaimana usaha dari subjek dalam mengatasi suatu permasalahan dalam pernikahan beda agama, tidak dapat mengandalkan satu pihak saja, melainkan harus datang dari pihak suami dan istri. Usaha yang dilakukan oleh partisipan antara lain dengan langsung mengkomunikasikan dengan pasangan dan ada yang lebih memilih untuk berpikir sendiri terlebih dahulu hingga menemukan solusi dari masalah yang terjadi (Pratiwi, 2014).

Penyelesaian konflik yang menyangkut perbedaan agama dalam kehidupan pernikahan tergantung dengan bagaimana cara pengelolaan konflik yang dilakukan oleh pasangan tersebut untuk mempertahankan keutuhan rumah tangganya. Adanya asumsi bahwa sebagian pasangan beda agama seringkali mengalami konflik yang mendalam dan beresiko kearah perceraian, hal tersebut dikarenakan 
adanya perbedaan yang terlihat jelas seperti perbedaan pandangan, perbedaan keyakinan, perbedaan nilai-nilai agama hingga bagaimana cara mengasuh anak (Agustin, 2013). Pada penelitian yang dilakukan oleh Agustin (2013), ditemukan bahwa beberapa partisipan menggunakan strategi dalam menyelesaikan konflik yang terjadi dalam kehidupan rumah tangganya. Strategi tersebut yaitu kompetisi (menguasai), penghindaran (menarik diri), kompromi (berunding), kolaborasi (menghadapi), dan akomodasi (melunak). Sebagian besar partisipan seringkali mengkomunikasikan permasalahan yang terjadi dengan saling membicarakan atau berkolaborasi dan berunding kepada pasangan guna menyelesaikan konflik sehingga mereka bekerja sama dan mencari jalan keluar dari permasalahan yang dihadapi tersebut. Suami maupun istri bersedia membuka diri sehingga dapat menghindarkan diri dari perasaan tertekan dan masalah yang terpendam dengan cara mengkomunikasikan perasaan satu sama lain (Agustin, 2013).

Pada penelitian ini lebih menitikberatkan pada bagaimana dnamika istri pada pernikahan beda agama karena sesuai dengan pernyataan Holahan dan Levenson yang menyatakan bahwa pada umumnya istri lebih memiliki perasaan yang sensitive daripada suami dalam menghadapi permasalahan di kehidupan pernikahannya (Lemme, 1995). Keadaan pernikahan yang berbeda dari pernikahan lainnya membuat para istri harus lebih berusaha memahami kehidupan pernikahannya dan harus memiliki ketahanan yang lebih dalam menghadapi sindiran-sindiran yang datang dari masyarakat luas dan resiko serta dampak yang terjadi. Pada penelitian yang dilakukan oleh Hutapea (2011) yang meneliti mengenai dinamika penyesuaian suami istri dalam perkawinan beda agama, menunjukkan hasil bahwa istri lebih mendapat tekanan dari lingkungan sosialnya terkait pernikahan tersebut. Istri juga merasa tertekan apabila suami menginginkan anak-anak mereka mengikuti agamanya, namun suami tidak bisa memberikan contoh kepada anak atau memberikan pendidikan agama sesuai yang diinginkan kepada anak (Hutapea, 2011). Pada penelitian lain yang dilakukan oleh Larasati dan Desiningrum (2016) menemukan hasil bahwa istri dalam pernikahan beda agama lebih rentan mendapatkan tanggapan negative dari lingkungan di sekitarnya mengenai pernikahan beda agama yang dijalani bersama suami (Larasati \& Desiningrum, 2016). Hal tersebut yang menjadikan masalah dalam kehidupan pernikahan lebih kompleks yang dirasakan oleh istri daripada suami pada pernikahan beda agama.

Melihat fenomena pernikahan beda agama yang memiliki berbagai permasalahan serta dampaknya, serta peranan dan tugas istri yang sangat berpengaruh dalam kehidupan pernikahan, hal inilah yang melatarbelakangi peneliti untuk mengkaji topik mengenai resiliensi seorang istri pada pernikahan beda agama. Peneliti ingin mendalami bagaimana dinamika resiliensi seorang istri yang memiliki suami dengan kepercayaan yang berbeda dengannya dan bagaimana dinamika keluarga tersebut, seperti bagaimana cara membesarkan anak dan apa saja konflik yang terjadi serta bagaimana cara penyelesaiannya. Sehingga tujuan penelitian ini adalah untuk menggambarkan dinamika resiliensi istri pada pernikahan beda agama sesuai dengan aspek-aspek dinamika resiliensi yang ditinjau berdasarkan risk and protective factors menurut teori resiliensi Wille, Bettge \& Ravens-Sieberer. Aspek-aspek dinamika resiliensi yang ingin digali pada penelitian ini sesuai dengan teori resiliensi antara lain bagaimana stres yang dihadapi oleh istri, bagaimana dukungan yang muncul sebagai faktor protektif yang datang dari orang terdekat, bagamana dampak sebagai faktor resiko, bagaimana kemampuan koping yang dimiliki oleh istri seperti bagaimana mengatur emosi dan mengelola stres, dan bagaimana istri pada pernikahan beda agama memaknai atau mendapatkan pembelajaran dari setiap konflik yang dihadapi selama kehidupan pernikahan beda agama yang ia jalani bersama suami. Hal ini perlu dikaji karena dapat memberikan informasi mengenai bagaimana kehidupan pernikahan dengan perbedaan agama dan bagaimana proses dinamika resiliensi yang terjadi pada seorang istri pada pernikahan beda agama, sehingga para calon pasangan maupun seorang istri pada pernikahan beda agama dapat 
memahami dan mengetahui bagaimana proses resiliensi yang terjadi pada kehidupan pernikahan beda agama.

\section{Desain Penelitian}

\section{E T O D E}

Penelitian ini menggunaan pendekatan kualitatif dengan tipe penelitian studi kasus intrinsik. Penulis memilih pendekatan kualitatif dengan tujuan untuk menggali secara mendalam dinamika resiliensi yang terjadi pada masing-masing istri pada pernikahan beda agama. Penulis juga memilih menggunakan studi kasus intrinsik untuk memahami kondisi pada penelitian ini secara utuh tanpa ada tujuan untuk menghasilkan konsep atau teori ataupun tanpa adanya upaya untuk melakukan generalisasi.

\section{Partisipan}

Partisipan dalam penelitian ini dipilih dengan teknik purposive berdasarkan kriteria-kriteria yang ditentukan oleh penulis, yaitu wanita yang telah menikah, memiliki suami yang berbeda agama dan bertempat tinggal di Jawa Timur.

\section{Prosedur}

Partisipan menunjukkan memenuhi kriteria sebagai partisipan dalam penelitian ini dengan tetap bertahan pada pernikahan beda agama bersama suami dan tetap menjalankan peran sebagai istri. Partisipan serta significant other atau orang terdekat partisipan bersedia dan tidak keberatan untuk menjadi partisipan dalam penelitian ini sesuai dengan yang tertulis dalam lembar informed consent.

\section{Teknik Penggalian Data}

Teknik penggalian data dilakukan melalui proses wawancara secara mendalam.

\section{Analisis Data}

Hasil data yang diperoleh kemudian dianalisis menggunakan teknik analisis tematik dengan menggunakan teori resiliensi Wille, Bettge \& Ravens-Sieberer. Pengujian kredibilitas yang digunakan penulis pada penelitian ini menggunakan metode triangulasi data, dimana untuk mendapatkan informasi tambahan terhadap partisipan, penulis melakukan wawancara pada orang terdekat partisipan sebagai significant other.

\section{HAS I L P EN ELITIAN}

Hasil dari penelitian ini menunjukkan bahwa masing-masing partisipan memiliki stres yang berbeda meskipun berada dalam kesamaan yaitu pernikahan beda agama yang sedang dijalani oleh masingmasing partisipan. Latar belakang agama keluarga juga berpengaruh pada stres yang dialami oleh masing-masing partisipan. Pada aspek faktor protektif sebelum pernikahan, kedua partisipan memiliki faktor protektif yang berbeda dimana partisipan SU memiliki personal resource yang dominan dan partisipan SM memiliki familian resource yang baik. Lalu, pada pernikahan saat ini partisipan SU memliki familian resource sebagai faktor protektif dan partisipan SM memiliki personal resource karena adanya nilai religiusitas. 
Pada aspek faktor resiko ditemukan bahwa latar belakang agama keluarga juga berpengaruh pada faktor resiko yang dimiliki oleh kedua partisipan. Partisipan SU dengan latar belakang keluarga yang memiliki agama yang sama, beresiko pada adanya sujektifitas agama yang akan berdampak pada keharmonisan dengan pasangan sedangkan partisipan SM dengan latar belakang keluarga yang memiliki perbedaan agama, beresiko pada adanya kebingungan yang dialami oleh anak untuk menentukan agama yang akan dianutnya. Faktor resiko pada pernikahan saat ini ditemukan pada partisipan SU bahwa nilai religiusitas yang tinggi berdampak pada adanya konflik yang terjadi ketika mengarahkan agama yang akan dianut oleh anak kedua, sedangkan pada partisipan SM karena berasal dari keluarga yang menganut agama yang berbeda, adanya nilai toleransi yang tinggi sehingga hal tersebut membuat anak membuat keputusan untuk berpindah agama.

Adanya kesamaan pada aspek kemampuan koping yang dimiliki oleh kedua partisipan, yaitu baik partisipan SU maupun SM memilih untuk menerapkan approach strategy untuk mengatasi konflik serta masalah yang terjadi dalam kehidupan pernikahannya. Namun, ada pula perbedaan pada aspek kemampuan koping, yaitu pada partisipan SU lebih menunjukkan problem focused coping sebagai cara yang partisipan pilih ketika menghadapi masalah, sedangkan pada partisipan SM lebih menggunakan keduanya, yaitu problem focused coping dan emotional focused coping ketika sedang terlibat masalah atau sedang menghadapi konflik pada kehidupan pernikahan beda agama yang sedang dijalani.

Pada aspek kompetensi Individu ditemukan bahwa partisipan SU menilai bahwa pernikahan beda agama yang ia jalani bersama suami tergolong unik, karena menurutnya dalam setahun, partisipan dapat merayakan hari raya kedua agama sekaligus, sedangkan pada partisipan SM memaknai pernikahan beda agama yang ia jalani bersama suami merupakan pernikahan yang suci, dimana tidak hanya ada interaksi antara suami dan istri saja, namun juga adanya interaksi dengan Tuhan yang membuat pernikahan tersebut semakin bermakna.

Tabel 1. Hasil analisis dinamika resiliensi istri pada pernikahan beda agama

\begin{tabular}{|c|c|c|c|c|}
\hline \multirow{2}{*}{ Label } & \multicolumn{2}{|c|}{$\begin{array}{c}\text { Sebelum pernikahan hingga awal } \\
\text { pernikahan }\end{array}$} & \multicolumn{2}{|c|}{ Pernikahan saat ini } \\
\hline & SU & SM & SU & SM \\
\hline Stres & $\begin{array}{l}\text { Adanya tekanan } \\
\text { untuk berpindah } \\
\text { agama. }\end{array}$ & $\begin{array}{l}\text { Adanya } \\
\text { permasalahan } \\
\text { dan konflik yang } \\
\text { datang dari aspek } \\
\text { internal seperti } \\
\text { status janda } \\
\text { partisipan, } \\
\text { penolakan anak } \\
\text { pertama } \\
\text { mengenai } \\
\text { keputusan untuk } \\
\text { menikah lagi }\end{array}$ & $\begin{array}{l}\text { Adanya } \\
\text { perbedaan } \\
\text { tujuan dan } \\
\text { harapan dengan } \\
\text { suami terkait } \\
\text { pemilihan } \\
\text { agama kepada } \\
\text { anak kedua serta } \\
\text { tuntutan kepada } \\
\text { suami terkait } \\
\text { pengajaran pada } \\
\text { anak. }\end{array}$ & $\begin{array}{l}\text { Adanya konflik } \\
\text { dengan anak- } \\
\text { anaknya baik } \\
\text { anak pertama } \\
\text { maupun anak } \\
\text { kedua yang } \\
\text { menimbulkan } \\
\text { perasaan kecewa. }\end{array}$ \\
\hline
\end{tabular}




\begin{tabular}{|c|c|c|c|c|}
\hline \multirow[t]{2}{*}{ Label } & \multicolumn{2}{|c|}{$\begin{array}{c}\text { Sebelum pernikahan hingga awal } \\
\text { pernikahan }\end{array}$} & \multicolumn{2}{|c|}{ Pernikahan saat ini } \\
\hline & SU & SM & SU & SM \\
\hline $\begin{array}{c}\text { Faktor } \\
\text { Protektif }\end{array}$ & $\begin{array}{l}\text { Memiliki personal } \\
\text { resource yang kuat } \\
\text { sebagai individu dan } \\
\text { temuan baru yaitu } \\
\text { nilai religiusitas yang } \\
\text { tinggi pada individu } \\
\text { membuat individu } \\
\text { memiliki personal } \\
\text { resource yang kuat, } \\
\text { karena adanya latar } \\
\text { belakang agama } \\
\text { keluarga dari } \\
\text { partisipan yang } \\
\text { bersifat homogen. }\end{array}$ & $\begin{array}{l}\text { Memiliki familian } \\
\text { resource yang baik } \\
\text { di lingkungan } \\
\text { individu karena } \\
\text { adanya latar } \\
\text { belakang agama } \\
\text { keluarga dari } \\
\text { keluarga partisipan } \\
\text { sebagai istri dan } \\
\text { significant other } \\
\text { sebagai suami yang } \\
\text { bersifat heterogen } \\
\text { sehingga } \\
\text { ditemukan nilai } \\
\text { toleransi sangat } \\
\text { tinggi. }\end{array}$ & $\begin{array}{l}\text { Familian } \\
\text { Resource sebagai } \\
\text { seorang ibu, } \\
\text { mengambil alih } \\
\text { pengajaran } \\
\text { agama anak } \\
\text { kedua dengan } \\
\text { mengajarkan } \\
\text { sesuai agama } \\
\text { Hindu. }\end{array}$ & $\begin{array}{l}\text { - Personal } \\
\text { Resource dengan } \\
\text { penemuan nilai } \\
\text { religiusitas yang } \\
\text { tinggi dari } \\
\text { individu yang } \\
\text { mempengaruhi } \\
\text { proses } \\
\text { resiliensi. } \\
\text { - Familian } \\
\text { Resource } \\
\text { mempengaruhi } \\
\text { keputusan SM } \\
\text { untuk bertindak } \\
\text { tegas sebagai } \\
\text { ibu kepada anak } \\
\text { pertama dengan } \\
\text { memberikan } \\
\text { disiplin atas } \\
\text { dasar } \\
\text { menyayangi. }\end{array}$ \\
\hline Faktor Resiko & $\begin{array}{l}\text { Latar belakang } \\
\text { agama dari keluarga } \\
\text { partisipan dan } \\
\text { keluarga suami yang } \\
\text { bersifat homogen } \\
\text { memiliki dampak } \\
\text { adanya subjektifitas } \\
\text { agama yang menjadi } \\
\text { resiko keharmonisan } \\
\text { pasangan } \\
\text { kedepannya. }\end{array}$ & $\begin{array}{l}\text { Latar belakang } \\
\text { agama dari } \\
\text { keluarga partisipan } \\
\text { dan keluarga suami } \\
\text { yang bersifat } \\
\text { heterogen memiliki } \\
\text { dampak adanya } \\
\text { kebingungan yang } \\
\text { terjadi pada anak } \\
\text { untuk menentukan } \\
\text { agamanya. }\end{array}$ & $\begin{array}{l}\text { Nilai religiusitas } \\
\text { yang tinggi } \\
\text { berdampak pada } \\
\text { adanya konflik } \\
\text { mengarahkan } \\
\text { agama sesuai } \\
\text { keinginan kepada } \\
\text { anak kedua. }\end{array}$ & $\begin{array}{l}\text { Faktor heterogen } \\
\text { dan nilai toleransi } \\
\text { yang ditanamkan } \\
\text { sejak dini kepada } \\
\text { anak berdampak } \\
\text { pada keputusan } \\
\text { anak untuk } \\
\text { berpindah agama, } \\
\text { sehingga hal } \\
\text { tersebut menjadi } \\
\text { resiko karena } \\
\text { adanya harapan } \\
\text { istri sebagai ibu } \\
\text { yang } \\
\text { menginginkan } \\
\text { anak mengikuti } \\
\text { agamanya. }\end{array}$ \\
\hline $\begin{array}{l}\text { Kemampuan } \\
\text { Koping }\end{array}$ & $\begin{array}{l}\text { Personal resource } \\
\text { yang tinggi } \\
\text { mempengaruhi } \\
\text { problem focused } \\
\text { coping partisipan } \\
\text { diawal dengan }\end{array}$ & $\begin{array}{l}\text { Nilai religiusitas } \\
\text { yang tinggi muncul } \\
\text { dan mempengaruhi } \\
\text { problem focused } \\
\text { coping dan } \\
\text { emotional focused }\end{array}$ & $\begin{array}{l}\text { Personal } \\
\text { Resource yang } \\
\text { kuat sebagai } \\
\text { faktor protektif } \\
\text { mempengaruhi } \\
\text { problem focused }\end{array}$ & $\begin{array}{l}\text { - Familian } \\
\text { Resource yang } \\
\text { kuat } \\
\text { mempengaruhi } \\
\text { SM untuk } \\
\text { menerima } \\
\end{array}$ \\
\hline
\end{tabular}




\begin{tabular}{|c|c|c|c|}
\hline \multirow[t]{2}{*}{ Label } & \multicolumn{2}{|c|}{$\begin{array}{c}\text { Sebelum pernikahan hingga awal } \\
\text { pernikahan }\end{array}$} & Pernikahan saat ini \\
\hline & SU & SM & SM \\
\hline $\begin{array}{c}\text { Kemampuan } \\
\text { Koping }\end{array}$ & $\begin{array}{l}\text { menceritakan } \\
\text { mengenai } \\
\text { agamanya dan } \\
\text { keinginannya } \\
\text { menikah dengan } \\
\text { menggunakan adat } \\
\text { serta prosesi } \\
\text { sesuai agama } \\
\text { Hindu. } \\
\text { - Selain itu personal } \\
\text { resource yang } \\
\text { tinggi membuat SU } \\
\text { berani } \\
\text { memberikan } \\
\text { ancaman kepada } \\
\text { suami (ditemukan } \\
\text { nilai agresifitas) } \\
\text { untuk } \\
\text { mempertahankan } \\
\text { agamanya ketika } \\
\text { mendapat tekanan } \\
\text { dari suami. }\end{array}$ & $\begin{array}{l}\text { coping seperti } \\
\text { mencari nasehat } \\
\text { dan solusi untuk } \\
\text { permasalahan atau } \\
\text { konflik yang } \\
\text { dihadapi dengan } \\
\text { melakukan } \\
\text { aktifitas seperti } \\
\text { membaca kitab } \\
\text { suci dan berdoa. }\end{array}$ & $\begin{array}{ll}\text { coping yang } & \text { keputusan anak } \\
\text { dilakukan } & \text { kedua untuk } \\
\text { partisipan seperti } & \text { menjadi mualaf } \\
\text { membatasi diri } & \text { (pergantian dari } \\
\text { dengan avoidance } & \text { agama Kristen } \\
\text { strategy untuk } & \text { ke Islam). } \\
\text { meminimalisir } & \text { - Selain itu } \\
\text { stressor seperti } & \text { familian } \\
\text { menghindari } & \text { resource juga } \\
\text { obrolan } & \text { mempengaruhi } \\
\text { mengenai agama } & \text { emotional } \\
\text { dengan suami. } & \text { focused coping } \\
& \text { dan problem } \\
& \text { focused coping } \\
& \text { karena SM } \\
& \text { menceritakan } \\
& \text { dan meminta } \\
& \text { saran anak } \\
& \text { kedua yang ia } \\
& \text { anggap telah } \\
& \text { dewasa dan } \\
& \text { mampu } \\
& \text { memberikan } \\
& \text { saran yang baik } \\
& \text { untuknya }\end{array}$ \\
\hline & & & $\begin{array}{l}\text { Approach strategy yang dimiliki kedua } \\
\text { partisipan dalam mengatasi konflik } \\
\text { serta permasalahan yang terjadi } \\
\text { dalam kehidupan rumah tangga } \\
\text { dengan suami yang memiliki } \\
\text { perbedaan agama. Kedua partisipan } \\
\text { memilih untuk mencari waktu yang } \\
\text { tepat untuk membahas kembali } \\
\text { konflik yang terjadi ketika suasana } \\
\text { telah kondusif dan tidak diliputi } \\
\text { emosi, untuk menemukan jalan tengah } \\
\text { dan mendapat solusi bersama untuk } \\
\text { menyelesaikan konflik. Selain itu } \\
\text { kedua partisipan tetap menjalankan } \\
\text { kewajibannya sebagai seorang istri } \\
\text { (untuk SU) seorang istri dan ibu } \\
\text { (untuk SM) ketika suaminya dan anak } \\
\text { (untuk SM) menjalankan ibadah } \\
\text { seperti puasa Ramadhan, }\end{array}$ \\
\hline
\end{tabular}




\begin{tabular}{|c|c|c|c|c|}
\hline \multirow{2}{*}{ Label } & \multicolumn{2}{|c|}{$\begin{array}{c}\text { Sebelum pernikahan hingga awal } \\
\text { pernikahan }\end{array}$} & \multicolumn{2}{|c|}{ Pernikahan saat ini } \\
\hline & SU & SM & SU & SM \\
\hline & & & $\begin{array}{l}\text { mempersiapkan s } \\
\text { serta tetap mer } \\
\text { pada hari raya Id } \\
\text { agama Islam yan } \\
\text { SU dan SM. }\end{array}$ & $\begin{array}{l}\text { hur dan buka puasa } \\
\text { iapkan keperluan } \\
\text { Fitri sesuai dengan } \\
\text { dianut oleh suami }\end{array}$ \\
\hline $\begin{array}{l}\text { Kompetensi } \\
\text { Individu }\end{array}$ & & & $\begin{array}{l}\text { Karena latar } \\
\text { belakang agama } \\
\text { keluarga SU yang } \\
\text { tergolong } \\
\text { homogen } \\
\text { menjadikan SU } \\
\text { menilai bahwa } \\
\text { pernikahan beda } \\
\text { agama yang ia } \\
\text { jalani bersama } \\
\text { suami tergolong } \\
\text { unik, karena } \\
\text { menurutnya } \\
\text { dalam setahun ia } \\
\text { dapat merayakan } \\
\text { hari raya dua } \\
\text { agama sekaligus. }\end{array}$ & $\begin{array}{l}\text { Nilai religiusitas } \\
\text { yang tinggi yang } \\
\text { ditemukan pada } \\
\text { SM membuat ia } \\
\text { memaknai } \\
\text { pernikahan beda } \\
\text { agamanya sebagai } \\
\text { pernikahan yang } \\
\text { suci dimana } \\
\text { sesuai dengan } \\
\text { ajaran agama } \\
\text { Kristen bahwa } \\
\text { pernikahan } \\
\text { disimbolkan } \\
\text { seperti tali tiga } \\
\text { rangkap, dimana } \\
\text { tidak hanya } \\
\text { interaksi antara } \\
\text { suami dan istri } \\
\text { namun } \\
\text { pernikahan juga } \\
\text { melibatkan } \\
\text { adanya campur } \\
\text { tangan Tuhan } \\
\text { didalamnya }\end{array}$ \\
\hline
\end{tabular}

\section{I S K U S I}

Pada penelitian ini, penulis menemukan bahwa walaupun kedua partisipan memiliki kesamaan sebagai istri pada pernikahan beda agama yang dijalani, namun stres, faktor protektif, faktor resiko, kemampuan koping serta kompetensi yang dimiliki oleh kedua partisipan sangat berbeda satu sama lain. pada aspek stres, SU mendapatkan tentangan dari pihak keluarga suami untuk berpindah agama dengan alasan nantinya ketika menjadi seorang istri, SU akan dibimbing oleh suami. Apabila sebagai seorang istri, SU memiliki kepercayaan yang berbeda dengan calon suami, hal tersebut dikhawatirkan akan menimbulkan konflik dalam kehidupan pernikahan SU dan suami. Ditemukan bahwa tekanan untuk berpindah agama yang datang dari pihak keluarga suami merupakan suatu bentuk stres, karena hal tersebut selaras dengan teori stress Lazarus yang menjelaskan bahwa stress merupakan keadaan yang tidak menyenangkan kepada individu akibat daripada adanya desakan dari keadaan sekeliling (Rose \& Mustafa, 2018). Respon yang diberikan oleh SU ketika menghadapi stres merupakan faktor 
protektif yang digolongkan ke dalam personal resource sesuai dengan perspektif teoritis dinamika resiliensi. Selain itu hal tersebut juga masuk pada aspek kemampuan koping dan tergolong pada indikator mengelola stressor (problem focused coping). Hal tersebut berdasar pada SU memiliki faktor khusus untuk individu yaitu pribadi yang berprinsip dengan memiliki self-efficacy yang tinggi (Wille dkk., 2008).

Aspek stress kembali terlihat di pernikahan beda agama pada saat ini yang dijalani oleh SU dan suami. SU menganggap bahwa suaminya kurang dapat mengajarkan tatacara dan memberikan contoh kepada anak keduanya mengenai agama atau ilmu Ketuhanan. Sehingga faktor protektif yang dipilih SU adalah familian resource. Sebagai ibu, dirinya bertanggung jawab membesarkan anak, menciptakan iklim keluarga yang baik dan kohesi. Selain itu SU juga bertanggung jawab untuk membentuk pola asuh yang pas untuk anak usia Taman Kanak-kanak (Wille dkk., 2008). Tindakan SU mengambil alih pengajaran anak dengan menggunakan agama Hindu mengenai ilmu Ketuhanan, juga masuk pada aspek kemampuan koping dengan indikator adaptif dan efisien serta indikator mengatur emosi yang timbul dari pertemuan yang penuh tekanan (emotional focused coping). SU sangat menghindari topik obrolan mengenai agama, karena SU mengaku bahwa emosinya mudah tersulut ketika mendengar apabila ada salah satu oknum yang mengatakan hal buruk mengenai satu agama. Alasannya adalah SU beranggapan bahwa semua agama mengajarkan hal yang baik, sehingga tidak perlu untuk saling berlomba mana agama yang paling baik. Hal tersebut sesuai dengan teori dari Santrock (2003) yang menjelaskan mengenai strategi menghindari (avoidance strategy) yang merupakan sebuah upaya untuk menyangkal atau meminimalisir stressor yang muncul dengan cara menghindari sumber konflik (Santrock, 2003). Namun, untuk permasalahan rumah tangga, seperti apabila SU menghadapi konflik dengan suaminya, SU akan memilih untuk menunggu waktu yang tepat dan kembali merundingkan masalah atau konflik rumah tangga bersama suaminya untuk menemukan jalan keluar dari permasalahan yang dihadapi. Cara menghadapi permasalahan rumah tangga yang dilakukan SU masuk ke dalam aspek kemampuan koping dengan indikator mengelola stressor. Hal tersebut dapat dikatakan bahwa SU menyelesaikan konflik rumah tangganya dengan menggunakan strategi pendekatan (approach strategy) (Santrock, 2003).

Faktor resiko yang terjadi pada sebelum pernikahan adalah adanya latar belakang agama dari keluarga SU dan suami yang masing-masing bersifat homogen atau memiliki agama yang sama dalam keluarga, beresiko akan memiliki dampak subjektifitas agama yang akan mempengaruhi keharmonisan pasangan pada pernikahan beda agama nantinya. Adanya faktor resiko tersebut yang menjadi alasan mengapa adanya tekanan dari keluarga pihak suami yang menuntut SU untuk berpindah agama mengikuti agama Islam. Hal tersebut didukung oleh pernyataan Sadarjoen (2005) yang mengatakan adanya perbedaan agama diantara pasangan nantinya akan berdampak pada perbedaan harapan dan tujuan pasanganan yang nantinya akan menjadi sumber konflik (Sadarjoen, 2005). Saat ini, kehidupan pernikahan beda agama yang SU dan suami jalani tergolong memiliki faktor protektif yang kuat sebagai familian resource karena SU menceritakan bahwa kehidupan pernikahan beda agama yang dia jalani bersama suami penuh dengan toleransi dan saling support. Terlebih ketika hari raya salah satu agama, seperti contoh pada agama Islam ketika hari raya Idul Fitri dan ibadah puasa Ramadhan, SU sebagai istri tetap melakukan kewajibannya untuk mengurus suami dengan baik.

Pada kehidupan pernikahan beda agama partisipan kedua yaitu seorang istri berinisial SM, diketahui aspek stress yang dimiliki pada sebelum pernikahan adalah adanya tentangan untuk SM menikah lagi, yang datang dari anak pertama SM pada pernikahan sebelumnya. SM menceritakan bahwa anak pertamanya tidak merelakan SM untuk menikah lagi. Hal tersebut tergolong ke dalam aspek stres bagi istri seperti pada perspektif teoritis dinamika resiliensi (Wille dkk., 2008). Respon yang diberikan oleh kedua orang tua SM pada saat itu adalah mereka sangat mendukung keputusan SM untuk menikah lagi. 
Kedua orang tua SM tidak mempermasalahkan adanya perbedaan agama diantara SM dan BW. Kedua orang tua SM malah memberikan nasehat dan mempercayakan kembali semuanya kepada SM sesuai kepercayaan agama yang dianut oleh SM yaitu agama Kristen. Dukungan yang datang dari orang tua merupakan salah satu faktor protektif bagi istri pada pernikahan beda agama (Wille dkk., 2008). Faktor protektif tersebut merupakan familian resource yang dimana orang tua memberikan dukungan kepada anaknya, dimana pada kasus ini orang tua SM sangat mendukung keputusan SM untuk menikah lagi walaupun dengan calon suami yang berbeda agama.

Pada awal pernikahan beda agama yang dijalani oleh SM dengan suami terdapat permasalahan serta konflik. Permasalahan yang terjadi adalah adanya tuntutan suami kepada SM terkait perubahan karakter yang dimiliki oleh SM. SM beranggapan bahwa tuntutan suaminya akan perubahan karakternya tidak pernah habis, karena SM merasa bahwa suaminya masih memandang diri SM masih kurang dan belum terdapat perubahan karakter yang signifikan walaupun SM telah berusaha merubah karakter sesuai dengan keinginan BW. Hal tersebut termasuk ke dalam aspek stres yang dialami oleh istri karena adanya tuntutan suami yang berlebihan membuat diri SM merasa terbebani, sehingga stres yang dialami oleh SM tergolong ke dalam indikator primary appraisal. Adanya tuntutan suami yang secara tidak langsung membebani SM didukung oleh Sadarjoen (2005) yang mengatakan bahwa perbedaan harapan diantara pasangan yang berbeda agama dapat menjadi sumber konflik (Sadarjoen, 2005).

Tuntutan akan perubahan karakter yang terjadi pada pernikahan beda agama yang dijalani oleh SM dan suami, menjadikan hal tersebut sebuah konflik tersendiri. Sehingga cara SM untuk mengatasi konflik yang terjadi dalam pernikahan beda agama yang ia jalani adalah dengan mengkomunikasikan kembali permasalahan yang terjadi dengan suaminya pada saat yang tepat ketika suasana sudah kembali dingin. Tujuan SM untuk mengkomunikasikan kembali permasalahan tersebut adalah untuk mencari solusi dan jalan keluar. Sehingga pemilihan penyelesaian konflik yang dipilih oleh SM adalah dengan menggunakan strategi pendekatan (approach strategy) (Santrock, 2003). Apabila ditinjau berdasarkan perspektif teoritis pada penelitian ini yang adalah teori dinamika resiliensi, kemampuan penyelesaian konflik yang dipilih oleh SM, termasuk ke dalam aspek kemampuan koping. Kemampuan koping yang dimiliki oleh SM adalah dengan mencari waktu yang tepat untuk kembali membicarakan permasalahan dan mencari jalan keluar bersama suami, sehingga hal tersebut tergolong ke dalam indikator problem focused coping dalam mengelola stressor.

Pernikahan kedua SM dengan BW sebagai suami keduanya, melahirkan satu anak perempuan yang merupakan anak kedua SM dan anak kandung dari BW. Pada awalnya anak kedua SM mengikuti keyakinan agama SM yaitu agama Kristen namun ketika sudah menginjak usia dewasa, anak tersebut memiliki pemikiran yang berbeda dan memutuskan untuk beralih mengikuti kepercayaan ayahnya yaitu BW yang beragama Islam. Keputusan anak kedua SM untuk menjadi mualaf sangat berdampak pada diri SM. Dampak tersebut termasuk pada aspek stres yang dialami oleh istri pada pernikahan beda agama. Stres yang dialami oleh SM tergolong pada penilaian utama atau primary appraisal. Menurut Lazarus (1984) adanya ketegangan yang dirasakan individu ketika berhadapan pada situasi atau mengalami peristiwa yang tidak diinginkan seperti kehilangan orang tersayang mengakibatkan individu mengalami emosi yag negative dan merasa terpuruk, dimana keadaan ini disebut dengan distress (Rose \& Mustafa, 2018). Diketahui pada saat anak kedua SM berpindah agama, seiring berjalannya waktu SM mulai menerima perubahan agama yang dimiliki oleh anak tersebut, sehingga dapat digolongkan SM memiliki kemampuan koping pada kedua indikator yaitu problem focused coping yang adalah mengelola stressor dan emotional focused coping yang adalah kemampuan SM untuk mengatur emosi yang timbul dari pertemuan yang penuh tekanan (Wille dkk., 2008). Sehingga, dinamika resiliensi istri pada pernikahan beda agama yang terlihat dari kedua partisipan menunjukkan bahwa adanya perbedaan 
proses resiliensi yang terjadi pada masing-masing partisipan di kehidupan pernikahan beda agama yang mereka jalani sebagai istri.

\section{S I M P U L A N}

Penelitian ini bertujuan untuk menggambarkan dinamika resiliensi istri pada pernikahan beda agama berdasarkan teori resiliensi Wille, Bettge, Ravens-Sieberer yang terdiri dari lima aspek yaitu stres, faktor protektif, faktor resiko, kemampuan koping dan kompetensi individu, dimana aspek-aspek tersebut mempengaruhi proses resiliensi istri pada pernikahan beda agama. Aspek stres, faktor protektif dan kompetensi individu yang ditemukan pada penelitian ini menunjukkan adanya perbedaan dari masing-masing partisipan yang dipengaruhi oleh latar belakang keluarga, terlebih pada latar belakang agama keluarga, sehingga dapat ditarik kesimpulan bahwa keluarga yang homogen secara agama yaitu keluarga yang hanya memiliki satu macam agama dalam interaksi keluarganya, lebih mendapatkan tekanan pada aspek stres untuk beralih kepercayaan jika istri terlibat pada pernikahan beda agama, memiliki personal resource yang tinggi pada faktor protektif untuk tetap mempertahankan prinsip serta kepercayaannya, lalu pada aspek individu, terlihat bahwa istri mampu secara adaptif dan efisien mengelola kehidupan rumah tangganya bersama suami, serta adanya sumber daya kognitif yang menilai bahwa pernikahan beda agama yang dijalani tergolong pernikahan yang unik karena adanya saling toleransi baik istri maupun suami pada saat hari raya agama. Sedangkan pada keluarga yang heterogen secara agama yaitu keluarga yang memiliki lebih dari satu macam agama dalam interaksi keluarganya, diketahui bahwa aspek stres yang terjadi rata-rata karena konflik dan permasalahan dalam keluarga bukan mengenai perbedaan agama, familian resource sangat kuat pada faktor protektifnya, dan pada kompetensi diketahui bahwa istri lebih mengandalkan Tuhan dan memaknai pernikahan yang dijalani tergolong pernikahan yang suci dimana pernikahan merupakan interaksi antara suami istri dengan Tuhan.

Faktor religiusitas menjadi temuan baru pada penelitian ini karena adanya faktor religiusitas hal tersebut dapat mempengaruhi bagaimana proses resiliensi dapat berjalan, didukung dengan adanya penguatan yang datang dari faktor protektif, kemampuan koping serta kompetensi individu, hal tersebut dapat membantu istri menjadi resilien di kehidupan pernikahan yang unik dan menantang dengan adanya perbedaan agama.

\section{U C A P A N T ERIMAKASIH}

Penyusunan artikel penelitian ini tidak terlepas dari dukungan dan doa dari beberapa pihak sehingga penulis ingin mengucapkan terima kasih kepada Ibu Ike Herdiana selaku dosen pembimbing skripsi Departemen Psikologi Kepribadian dan Sosial Fakultas Psikologi Universitas Airlangga yang telah banyak membantu, memberikan bimbingan, memberikan arahan serta nasehat kepada penulis dalam menyelesaikan penelitian ini. Terima kasih untuk kedua orang tua, keluarga serta sahabat dan teman dekat penilis yang selalu setia mendampingi dan mendoakan serta memberikan dukungan yang tidak pernah berhenti sehingga penulis dapat menyelesaikan penelitian ini. Penulis juga mengucapkan terima kasih kepada seluruh partisipan yang telah bersedia untuk meluangkan waktunya dan berpartisipasi dalam penelitian ini. 


\section{DEKLARAS I POTENSI TERJADINYA KONFLIK KEPENTINGAN}

Titania Caesary Rachmadhani dan Ike Herdiana tidak bekerja, menjadi konsultan, memiliki saham atau menerima dana dari perusahaan atau organisasi manapun yang akan mengambil untung dari naskah ini, dan telah mengungkapkan bahwa ia tidak memiliki afiliasi selain yang telah disebut di atas.

\section{PUSTAKA ACUAN}

Agustin, A. (2013). MANAJEMEN KONFLIK ANTARPRIBADI PASANGAN SUAMI ISTRI BEDA AGAMA. 10.

Akbar, C. (2020, Maret 31). Sejak 2004-2011 Ada 1190 Pernikahan Beda Agama. Hidayatullah.com. https://www.hidayatullah.com/berita/nasional/read/2012/03/31/58025/sejak-2004-2011ada-1190-pernikahan-beda-agama.html

Dariyo, A. (2003). Psikologi Perkembangan Dewasa Muda (Jakarta). P. Grasindo Anggota Ikapi.

Hikmatunnisa, M., \& Takwin, B. (2007). Pengaruh Perbedaan Agama Orang tua terhadap Psychological Well-Being dan Komitmen Beragama Anak. Jurnal Psikologi Sosial, 13, 157-165.

Hutapea, B. (2011). DINAMIKA PENYESUAIAN SUAMI -ISTRI DALAM PERKAWINAN BERBEDAAGAMA. 16(01), 18.

Larasati, S., \& Desiningrum, D. R. (2016). PENGALAMAN MENIKAH BEDA AGAMA (SEBUAH INTERPRETATIVE PHENOMENOLOGICAL ANALYSIS). 5, 6.

Lemme, B. H. (1995). Development in Adulthood (USA). Allyn \& Bacon.

Pratiwi, I. (2014). Pernikahan Pasangan Beda Agama [Skripsi]. Universitas Muhammadiyah Surakarta.

Rose, N. N., \& Mustafa, M. Y. (2018). Stress Among Working Women: Counselling Services Using the Lazarus Stress Theory and the Practice of Solution-Focused Therapy. Asian Social Work Journal, 3(1), 28-34. https://doi.org/10.47405/aswj.v3i1.30

Sadarjoen, S. S. (2005). Konflik Marital (Bandung). Refika Aditama.

Santrock, J. W. (2003). Adolescence: Perkembangan remaja (Jakarta). Erlangga.

Wille, N., Bettge, S., \& Ravens-Sieberer, U. (2008). Risk and protective factors for children's and adolescents' mental health: Results of the BELLA study. European Child \& Adolescent Psychiatry, 17(S1), 133-147. https://doi.org/10.1007/s00787-008-1015-y 